\title{
No Common Ground? Public Knowledge about Welfare Spending in Turkey and its Social Divisions
}

\author{
Volkan Yilmaz* (D) and Anil Gurbuzturk** \\ *School of Law and Government, Dublin City University, Dublin, Ireland. \\ E-mail: volkan.yilmaz@dcu.ie \\ **Social Policy Forum Research Centre, Bogazici University, Istanbul, Turkey. \\ E-mail: anilgurbuzturk92@gmail.com
}

Social policy research examining citizens' welfare knowledge, which offers a gateway to their understanding of the policy context, has remained limited. Adapting the opportunity-motivation-ability framework borrowed from the literature on political knowledge to welfare knowledge, this article offers an analysis of new data from a nationwide survey to explore Turkish society's knowledge of the composition of public social spending. Corroborating earlier findings in the literature, the article maintains that most people in Turkey overestimate the relative size of social assistance spending for the poor. However, different from previous findings, the majority and most pensioners are also ill-informed about the rank of public spending on old-age pensions, the most widely used social benefit absorbing the largest share of welfare spending. The article provides evidence of the social division of welfare knowledge in Turkish society based mostly on three opportunity-related variables: city of residence, gender and income.

Keywords: Political knowledge, social spending, welfare knowledge, welfare spending, Turkey.

\section{Introduction}

Only a few social policy studies have investigated people's knowledge of welfare policies (Taylor-Gooby et al., 2003; Wilson et al., 2012). While the theoretical basis for studying welfare knowledge is scant, the benefits of doing so are potentially substantial. First, welfare knowledge is an entry point to citizens' understanding of the policy context, which can shape the public debate on social policies (Taylor-Gooby et al., 2003: 2). Despite contradictory results in the literature on the effect of knowledge on policy attitudes (Barnes et al., 2018), there is evidence to suggest that enhanced availability of knowledge of the policy context has the power to change the policy preferences of less knowledgeable people (Naumann, 2017). In other words, citizens' lack of knowledge about the policy context might lead them to hold political views different from those they would adopt otherwise (Gilens, 2001). Nevertheless, it would be naïve to assume that improved knowledge would lead citizens to hold uniform views on policies. They would use this knowledge in a manner consistent with their reasoning and values in relation to diverse policy issues (Stantcheva, 2020). Second, when citizens lack accurate welfare knowledge, they might not be able to identify their self-interest. Therefore, a focus on 
welfare knowledge allows us to re-examine the assumption that well-informed citizens form their attitudes based on self-interest (e.g. Degen et al., 2019) and express them through voting.

Single-country studies on welfare knowledge (versus comparative studies) offer many advantages; for example, they can provide information on local welfare knowledge and within-country divisions - data that are not covered in the available comparative data. In this way, researchers can design a questionnaire that is tailored to the distinct features of the welfare system under consideration. In order to exploit this advantage of using a case study, this article includes local social policy context and policy-specific motivation in the analyses of the social division of welfare knowledge.

This study uses Turkey as a case in point to explore welfare knowledge and its social divisions in a pension-heavy welfare system. The literature on welfare knowledge focuses mostly on countries with liberal welfare systems (i.e. Australia and the UK) where the share of government spending on social services (health, education and other social services) is comparatively higher than cash benefits (OECD, 2020). For the cases of Australia and the UK, scholars found that the general public accurately perceived the size of the largest welfare spending items while overestimating that of targeted benefits for the unemployed and single mothers and underestimating that of old-age pensions (Taylor-Gooby et al., 2003; Wilson et al., 2012). We think that the majority's overall accurate perception of social spending in these countries might be due to their social services-dominated welfare budget architecture. This could be because spending on social services (including education and healthcare) might be more easily conceived by the general public as they are relevant to the lives of a broader population. In contrast, government spending on old-age pensions is the largest item in the Turkish case and cash benefits dominate the public welfare budget. Therefore, we hypothesise that the cash benefits-dominated character of Turkey's welfare system results in higher rates of inaccurate beliefs about the composition of social spending. The Turkish case also enables us to test whether the general public accurately perceives the size of public spending on old-age pensions when they constitute the largest item in the welfare budget. We consider Turkey an interesting case to investigate whether and to what extent political polarisation determines people's welfare knowledge, as previous research demonstrated that populism results in polarisation along political lines regarding the public perception of facts (Alesina et al., 2020).

Against this background, this article explores the following questions: To what extent does the Turkish population's knowledge about public social spending correspond to the actual social policy context? If they diverge considerably, which factors explain this divergence? This article uses new data from a major nationwide survey to explore the knowledge of the Turkish public about the social policy context using its knowledge about the composition of public social spending.

\section{Literature review}

Among the few studies on welfare knowledge, a UK case study found that the British public held reasonably accurate beliefs about the overall composition of social spending. Nevertheless, it demonstrated that they perceived public spending on the unemployed and single parents to be higher than it actually was (Taylor-Gooby et al., 2003: 7). The study concluded that people's level of welfare knowledge and the accuracy of their 
knowledge vary according to the particular area of social policy (Taylor-Gooby et al., 2003: 8). Another study by Wilson et al. (2012: 339-41) examined how accurately Australians assessed the impact of the Howard government's welfare reforms. Their study showed that, while more voters accurately assessed the gains of the middle class, they underestimated the significant losses of single parents and the unemployed. Finally, a mixed-methods study on Ghana demonstrated that individuals are less knowledgeable about targeted social policy programmes than universal ones (Amoah, 2020). Combined, these studies provide substantial evidence of the existence of a social division of welfare knowledge in a variety of societies. Nevertheless, the limited literature on welfare knowledge does not offer a theoretical framework to guide further studies.

To compensate for this deficiency, we rely on the opportunity-motivation-ability framework that the literature on political knowledge provides. Despite the lack of scholarly interest in the issue among social policy scholars, political science research on political knowledge emerged in the 1980s and has flourished since then. Delli Carpini and Keeter (1993) define political knowledge as factually accurate knowledge about politics rooted in citizens' conscious memory. They maintain that 'political knowledge is to democratic politics what money is to economics: it is the currency of citizenship' (Delli Carpini and Keeter, 1996: 8).

Welfare knowledge can be considered a subset of political knowledge. Following in the footsteps of Delli Carpini and Keeter (1996), it may be considered the currency of social politics and social citizenship. However, an influential study showed that research on general political knowledge failed to capture citizens' policy-specific knowledge (Gilens, 2001). Therefore, predicting welfare knowledge based on overall political knowledge is misleading as the latter fails to measure policy-specific knowledge (Gilens, 2001). This makes it worthwhile to examine welfare knowledge as a distinct subject, involving knowledge of several social policies.

Our aim is to use the general framework within which the determinants of political knowledge are theorised, while changing the content of the knowledge that we measure. We operationalise people's welfare knowledge as their knowledge about the composition of public social expenditures in four broad social policy domains in Turkey (education, healthcare, old-age pensions and social assistance). We define the social policy context as the factual composition of public social expenditures in these social policy domains.

Delli Carpini and Keeter (1996) identify three determinants of political knowledge: opportunity, motivation and ability. They argue that individuals vary in these characteristics, which explains the social division of political knowledge in a given society.

First, opportunity refers to an environment-level variable (Luskin, 1990) that shapes the availability of knowledge to individuals. It is often operationalised with individuallevel variables, such as gender, age and income, which are related to the different positions that individuals hold in the social structure (Jerit et al., 2006). Based on the findings of Grönlund and Milner's study (2006), we expect that individuals with a higher income will have more accurate welfare knowledge. Dow (2009) identifies a gender gap in political knowledge, which he explains is based on the gendered differences in political socialisation. Following Dow's insights, we anticipate that, on average, women will have less accurate knowledge about the composition of public social spending and the relative sizes of major spending areas. Concerning age, in line with the results of Stockemer and Rocher's study (2017), we predict that the elderly will have more accurate welfare 
knowledge. In addition to these, we examine the local social policy context, measured using the city of residence, which is also found to shape opportunities for individuals to acquire welfare knowledge (Johansson Sevä, 2009). We hypothesise that the prevalence of high social risks in the local social policy context within which individuals are embedded will decrease the accuracy of their welfare knowledge.

Second, motivation corresponds to individuals' desire to acquire political knowledge (Delli Carpini and Keeter, 1996). In line with Miller and Rahn's approach (2002), we operationalise motivation as political interest emerging from individuals' commitment to particular political identities. We anticipate that, on average, individuals voting for the governing electoral coalition in Turkey are relatively ill-informed about the composition of welfare spending. We base this prediction on Jerit and Barabas' study (2012: 672), which suggested that 'people perceive the world in a manner consistent with their views', especially where high-publicity issues are concerned. Given the high publicity of recent reforms in healthcare and social assistance in our selected case, we expect that individuals voting for the governing electoral coalition will inaccurately place these domains higher in the ranking of social spending. In addition, we define a new variable of policy-specific motivation to measure individuals' knowledge of public spending on social policy programmes when they are potential beneficiaries of those programmes. We anticipate that, on average, individuals with a stake in a policy programme will have more accurate knowledge about the rank of the spending on this programme. Relying on the results of Taylor-Gooby et al. (2003), we also hypothesise that the size of public social spending known by one group may not be known by another, and these divisions can be explained by individuals' policy-specific motivations.

Third, ability is often understood as cognitive ability and measured using educational attainment (Delli Carpini and Keeter, 1996). We use educational attainment to measure the ability of individuals to have accurate knowledge of the composition of welfare spending. In light of the literature (Grönlund and Milner, 2006), we expect that individuals with a higher level of education will be better situated to have accurate welfare knowledge. We also predict that the impact of education on the social division of welfare knowledge in Turkey will be more pronounced than in more egalitarian countries, as its impact is greater in countries with unequal income distribution (Grönlund and Milner, 2006).

\section{The Turkish welfare system and the composition of social spending}

The Turkish welfare system has been likened to that of the Southern European cluster (Buğra and Keyder, 2006). In terms of composition, it has been heavily skewed toward old-age pensions, and its social assistance component is limited (Buğra and Keyder, 2006: 212). In the literature on welfare systems in developing countries, Rudra (2008: 390) classifies the Turkish welfare system as a protective regime due to its reliance on social insurance programmes, especially old-age pensions.

Turkey's welfare system has been expanding over the last decade (Yörük, 2020), which has led to an overall increase in social spending (Buğra, 2018: 323). This expansion has been accompanied by increased political polarisation (Erdoğan and Uyan Semerci, 2018) and the Justice and Development Party-led (AKP) government's instrumentalisation of social assistance for political purposes (Yörük, 2012). Despite the expansion of the welfare system, the share of public social expenditures in Turkey's Gross Domestic Product (GDP) was almost 8 points below the 20 per cent average for the OECD countries 
Table 1 Share of public spending on four major areas of social policy in GDP

\begin{tabular}{lc}
\hline \hline & Share in GDP (per cent) \\
\hline Old-age pensions & $7.72^{*}$ \\
Social assistance & $1.33^{* *}$ \\
Healthcare & $3.38^{*}$ \\
Education & $3.77^{* * *}$ \\
\hline \hline
\end{tabular}

Note. *for the year 2016 (OECD, 2020), **for the year 2015 (World Bank, 2018),

***for the year 2015 (OECD, 2020).

in 2019 (OECD, 2020), indicating that Turkey's overall welfare effort is still limited compared to that of other OECD countries.

The increase in social spending in the last decade can mainly be attributed to two factors. The first is the expansion (Yörük, 2020) and diversification of social assistance programmes in the last decade (Yentürk, 2013: 438). Nevertheless, social assistance still constitutes a relatively small fraction of total public social spending compared to other spending areas such as old-age pensions, education and healthcare (Yentürk, 2015). In 2015, social assistance was the smallest social spending item at 1.33 per cent of GDP (World Bank, 2018). Second, the growth in social spending over the last decade is also due to increased old-age pension spending. Between 2001 and 2016, the share of old-age pension spending rose from 4.33 per cent of GDP to 7.72 per cent (OECD, 2020). In 2016, more than 7.5 million people were receiving a retirement pension in Turkey, making oldage pensions the most commonly used social transfer programme in the country.

The public pension system in Turkey is thus the largest spending item of public social expenditures. The second-largest share of public spending goes to education, at 3.77 per cent of GDP in 2015, up from 2.45 per cent in 2000 (OECD, 2020). The third-largest is healthcare, which accounted for 3.38 per cent of GDP in 2016, up slightly from 3.31 per cent in 2001 (OECD, 2020)(OECD, 2020). Table 1 displays the share of public spending on four major areas of social policy in Turkey.

\section{Methods}

This study uses new data from a nationwide survey to explore Turkish society's knowledge of the composition of public social spending. The survey was developed by a group of researchers that included the authors and was implemented by an external professional survey company. To the best of our knowledge, it is the only nationally representative data on welfare knowledge in Turkey. The data were gathered in January and February 2019 from a sample of individuals aged eighteen years and older. The survey used multistage stratified random sampling based on the Nomenclature of Territorial Units for Statistics (NUTS-1 level) used by the Turkish Statistical Institution, which consists of twelve regions. Thus, a sample of 2,272 respondents that represent the Turkish population was obtained (the confidence level was 95 per cent; the margin of error was \pm 2.06 ). Face-to-face interviews were conducted with respondents in their homes. The Institutional Review Board of Boğaziçi University granted ethical approval for this study (number 2018/21). 
Dependent variables are respondents' knowledge about the relative sizes of four major social policy areas in total public social spending. In the survey, respondents were asked to rank these public social spending items from the largest to the smallest. At the coding stage, the data were transformed into binary variables based on the following rationale. We determined the accuracy of the responses in light of the actual composition of welfare spending in Turkey. For the Turkish case, pension is the largest and social assistance is the smallest area of government expenditure. If respondents listed old-age pensions as the largest or the second-largest expenditure, that was accepted as reasonably accurate. If respondents predicted social assistance as the smallest or the second-smallest expenditure, these answers were also accepted as reasonably accurate. If respondents did not list education expenditure as the lowest or the highest, the answer was taken as reasonably accurate. The same was done for healthcare.

The independent variables were grouped into three: opportunity, motivation and ability. For opportunity, the variables were gender, age group, household income and city of residence. Male was used as the reference category in gender. Age was sub-divided into three groups: eighteen to twenty-four (reference category), twenty- five to fifty-four and fifty-five and older. Monthly household income was sub-divided into three categories: 2,000 TL or less (reference category); between 2,001 and 5,000 TL; and 5,001 TL or more. For city of residence, living in the largest metropolitan city - Istanbul - was grouped into a single category and coded as a dummy variable.

For motivation, we used voting behaviour and four policy-specific motivation variables for each policy area. Voting behaviour was coded into three categories: The People's Alliance (reference category), which includes the governing AKP and the Nationalist Action Party (MHP); the Nation Alliance, which includes the Republican People's Party (CHP) and the Good Party (IYI Party); and the People's Democratic Party (HDP). Policy-specific motivation variables and their corresponding policy areas were as follows: pensioners for old-age pensions, living with a disabled person for social assistance, living with an unregistered employee for healthcare and living with a school-age child for education. Except for pensioners, these variables were selected as proxies for eligibility to benefit from the selected policy programmes. Based on Cramer and Toff's (2017) suggestion that political knowledge originates partly from the lived experiences of individuals, we expect these variables to express beneficiaries' subjective evaluation of the generosity of certain social policy programmes.

Finally, for ability, we used educational attainment. This was coded into three categories: secondary school graduate or below (reference category), high school graduate and college/university graduate or above. Table 2 presents the frequencies of these independent variables used in the regression model.

To examine the social division of welfare knowledge, hierarchical logistic regression was performed to investigate how determinants related to opportunity, motivation and ability influenced the respondents' predictions of government expenditure on oldage pensions, social assistance, healthcare and education. The dependent variables used in the hierarchical logistic regression were respondents' predictions of the ranking of public social expenditures on old-age pensions, social assistance, healthcare and education. Data were analysed using SPSS 27 (64-bit) for macOS. 
Table 2 Variables used in the regression model

\begin{tabular}{lrr}
\hline \hline & Frequency & Per cent \\
\hline Female & 1,126 & 49.6 \\
$18-24$ & 353 & 15.5 \\
$25-54$ & 1,631 & 71.8 \\
55 and above & 287 & 12.6 \\
2000 TL and below & 353 & 15.5 \\
$2001-5000$ TL & 1,631 & 71.8 \\
5001 TL and above & 287 & 12.6 \\
Living in Istanbul & 417 & 18.4 \\
The People's Alliance & 1,000 & 44.0 \\
The Nation's Alliance & 650 & 28.6 \\
People's Democratic Party & 163 & 7.2 \\
Non-voter/No answer & 458 & 20.2 \\
Retired & 205 & 9.1 \\
Living with a disabled person & 249 & 11.0 \\
Living with an unregistered employee & 404 & 17.9 \\
Living with a school-age child & 826 & 36.4 \\
Secondary school graduate or below & 954 & 42.0 \\
High school graduate & 852 & 37.5 \\
College or university graduate or above & 464 & 20.5 \\
\hline \hline
\end{tabular}

Note. Non-response never greater than 9.3.

\section{Findings}

The Turkish public's perception of welfare spending significantly differs from the actual composition. Table 3 displays the frequencies of reasonably accurate knowledge about the composition of public social spending.

While the actual size of public spending on old-age pensions is clearly the largest, only 38.5 per cent of the respondents ranked this as either the largest or the second-largest public spending item. The smallest expenditure item is social assistance, but the majority (59 per cent) of the respondents significantly overestimated social assistance spending, ranking it as either the largest or the second-largest area of public social spending. Almost two-thirds of the respondents have relatively accurate knowledge about the size of social spending on healthcare and education. The study shows that most people are ill-informed about the relative size of both targeted social assistance spending for the poor and old-age pensions, with the latter being the most widely used social benefit programme in the country. In contrast, the majority is well-informed about the size of spending on healthcare and education.

Table 4 presents the summarised results of the hierarchical logistic regression model developed to examine how determinants related to opportunity, motivation and ability influenced the respondents' knowledge of public spending on old-age pensions, social assistance, healthcare and education. The first block represents the first model using the opportunity, motivation and ability variables. In the second model, we added 
Table 3 Reasonably accurate knowledge on social spending

\begin{tabular}{lcc}
\hline \hline & Frequency & Per cent \\
\hline $\begin{array}{l}\text { Reasonably accurate knowledge on the ranking of old-age } \\
\text { pensions spending }\end{array}$ & 871 & 38.5 \\
$\begin{array}{l}\text { Reasonably accurate knowledge on the ranking of social } \\
\text { assistance spending }\end{array}$ & 927 & 41.0 \\
$\begin{array}{l}\text { Reasonably accurate knowledge on the ranking of healthcare } \\
\text { spending }\end{array}$ & 1,434 & 63.4 \\
$\begin{array}{l}\text { Reasonably accurate knowledge on the ranking of education } \\
\text { spending }\end{array}$ & 1,391 & 61.5 \\
\hline \hline
\end{tabular}

Note. Non-response never greater than 9.3.

policy-specific motivation to the model as an additional variable without omitting the opportunity, motivation and ability variables used in the first model.

In the first model, the following three categories were significant independent variables for reasonably accurate knowledge about the rank of public spending on old-age pensions: gender, income and city of residence. A logistic regression as shown in Table 4 indicated that the odds ratio of reasonably accurate knowledge about the rank of public spending on old-age pensions was 1.248 times greater for women than for men. Our finding that women, on average, have more accurate knowledge about the relative size of public old-age pensions spending disproves the hypothesis that we generated in light of previous studies (Dow, 2009) that indicated a clear gender gap in political knowledge.

Middle-income respondents were 0.767 times less likely to estimate pension spending ranking reasonably accurately than low-income respondents. Similarly, high-income respondents (respondents whose monthly income is 5,001 TL or more) were 0.609 times less likely to predict with reasonable accuracy the rank of public expenditures on pensions than low-income respondents. Our finding that middle-income and high-income individuals are less informed about the relative size of public old-age pensions spending does not support the hypothesis we generated based on Grönlund and Milner's study (2006) that predicted the opposite effect. We observed that low-income respondents had higher odds ratios of reasonably accurate knowledge about old-age pension spending. This might be explained by the fact that high- and middle-income respondents find old-age pension payments inadequate, while low-income respondents might be part of the informal labour market and desire to work in occupations where they can achieve formal retirement. Thus, low-income respondents' prediction of public spending on old-age pensions might reflect their aspirations to become pensionable in the future and their motivation to acquire knowledge about old-age pensions.

The analysis using the first model showed that the odds of reasonably accurate pension estimation were 1.972 times higher for respondents who live in Istanbul than for respondents who live in other cities of Turkey. The city of residence variable had a similar impact on the respondents' knowledge of education spending. Respondents who live in Istanbul were 1.310 times more likely to accurately estimate the relative size of public spending on education than respondents who live in other cities of Turkey. For social 
Table 4 Hierarchical regression models

\begin{tabular}{|c|c|c|c|c|c|c|c|c|}
\hline & \multicolumn{2}{|l|}{ Pension } & \multicolumn{2}{|c|}{ Social Assistance } & \multicolumn{2}{|l|}{ Healthcare } & \multicolumn{2}{|l|}{ Education } \\
\hline & Model 1 & Model 2 & Model 1 & Model 2 & Model 1 & Model 2 & Model 1 & Model 2 \\
\hline \multicolumn{9}{|l|}{$\overline{\text { Opportunity }}$} \\
\hline \multicolumn{9}{|l|}{ Gender (ref: male) } \\
\hline Female & $1.248^{*}$ & $1.209^{*}$ & 0.979 & 0.976 & 0.988 & 0.987 & 1.002 & 1.001 \\
\hline \multicolumn{9}{|l|}{ Age (ref: $18-24$ age group) } \\
\hline $25-54$ age group & 1.095 & 1.135 & 1.073 & 1.072 & $1.303^{*}$ & 1.295 & 1.003 & 1.046 \\
\hline 55 and above & 0.849 & 1.027 & 1.299 & 1.296 & 1.306 & 1.295 & 1.161 & 1.173 \\
\hline \multicolumn{9}{|l|}{$\begin{array}{l}\text { Income (ref: } 2000 \text { TL and } \\
\text { below monthly income) }\end{array}$} \\
\hline $\begin{array}{l}\text { Middle income 2001-5000 } \\
\text { TL }\end{array}$ & $0.767^{*}$ & $0.770^{*}$ & 0.915 & 0.928 & 0.904 & 0.903 & 1.110 & 1.116 \\
\hline $\begin{array}{l}5001 \mathrm{TL} \text { and above monthly } \\
\text { income }\end{array}$ & $0.609 * *$ & $0.614^{* *}$ & 0.812 & 0.829 & 0.768 & 0.765 & 0.851 & 0.853 \\
\hline \multicolumn{9}{|l|}{$\begin{array}{l}\text { City of residence (local } \\
\text { social policy context) }\end{array}$} \\
\hline İstanbul & $1.972 * * *$ & $2.005^{* * *}$ & $0.655^{* * *}$ & $0.658^{* * *}$ & 1.184 & 1.181 & $1.310^{*}$ & $1.303^{*}$ \\
\hline \multicolumn{9}{|l|}{ Motivation } \\
\hline \multicolumn{9}{|l|}{$\begin{array}{l}\text { Voting Behaviour (ref: The } \\
\text { People's Alliance) }\end{array}$} \\
\hline The Nation's Alliance & 1.175 & 1.167 & 0.881 & 0.878 & 1.150 & 1.148 & $0.819 *$ & 0.816 \\
\hline People's Democratic Party & 1.199 & 1.173 & 1.127 & 1.118 & 1.111 & 1.125 & 0.933 & 0.933 \\
\hline Non-voters/no answer & 1.203 & 1.205 & 1.003 & 0.998 & 1.182 & 1.187 & 0.952 & 0.951 \\
\hline \multicolumn{9}{|l|}{ Policy-Specific Motivation } \\
\hline Pensioner & & $0.663 *$ & & & & & & \\
\hline $\begin{array}{l}\text { Living with a disabled } \\
\text { person }\end{array}$ & & & & 1.186 & & & & \\
\hline
\end{tabular}




\begin{tabular}{|c|c|c|c|c|c|c|c|c|}
\hline & \multicolumn{2}{|l|}{ Pension } & \multicolumn{2}{|c|}{ Social Assistance } & \multicolumn{2}{|l|}{ Healthcare } & \multicolumn{2}{|l|}{ Education } \\
\hline & Model 1 & Model 2 & Model 1 & Model 2 & Model 1 & Model 2 & Model 1 & Model 2 \\
\hline $\begin{array}{l}\text { Living with an unregistered } \\
\text { employee }\end{array}$ & & & & & & 0.942 & & \\
\hline $\begin{array}{l}\text { Living with a school-age } \\
\text { child }\end{array}$ & & & & & & & & 0.908 \\
\hline \multicolumn{9}{|l|}{ Ability } \\
\hline \multicolumn{9}{|l|}{$\begin{array}{l}\text { Educational Attainment (ref: } \\
\text { secondary school graduate } \\
\text { or below) }\end{array}$} \\
\hline High school graduate & 0.912 & 0.918 & 1.132 & 1.130 & 1.052 & 1.051 & 1.027 & 1.022 \\
\hline $\begin{array}{l}\text { College or university } \\
\text { graduate or above }\end{array}$ & 0.890 & 0.887 & 1.001 & 0.997 & 0.975 & 0.974 & 1.039 & 1.019 \\
\hline Constant & $0.572 * * *$ & $0.571^{* *}$ & 0.741 & 0.721 & 1.361 & 1.385 & $1.493^{*}$ & $1.506^{*}$ \\
\hline Nagelkerke R Square & 0.033 & 0.036 & 0.014 & 0.015 & 0.007 & 0.007 & 0.008 & 0.008 \\
\hline Chi-square & $55.572^{* * *}$ & $60.877^{* * *}$ & $24.021^{*}$ & $25.558 *$ & 11.738 & 11.996 & 12.811 & 13.784 \\
\hline N & 2272 & 2272 & 2272 & 2272 & 2272 & 2272 & 2272 & 2272 \\
\hline
\end{tabular}

Note. The table reports odd ratios. $p$-values: ${ }^{*} p<0.5,{ }^{* *} p<0.01,{ }^{* * *} p<0.001$. 
assistance spending, the only significant independent variable in the first model was city of residence, but its impact was the opposite. In terms of knowledge about the rank of public spending on social assistance, a hierarchical logistic regression showed that the odds ratio for reasonably accurate knowledge was 0.655 times lower for respondents who live in Istanbul than for respondents who live in other cities of Turkey.

Our expectation based on Stockemer and Rocher's study (2017) that older age, another opportunity variable, would predict high levels of accuracy in welfare knowledge was not met, with the exception of healthcare. Regarding knowledge about the rank of public spending on healthcare, the first model showed that the odds ratio of reasonably accurate knowledge was 1.303 times greater for respondents in the twenty- five to fiftyfour age group than for those in the eighteen to twenty-four age group.

Voting behaviour was only found to be significant in predicting respondents' knowledge of education spending. The regression model showed that the odds of reasonably accurate education estimation were 0.819 times smaller for respondents who voted for the Nation's Alliance than for respondents who voted for the People's Alliance.

Concerning ability-related determinants of welfare knowledge, more educated people were found to be better informed about the composition of public social spending than the general population (Taylor-Gooby et al., 2003: 13; Wilson et al., 2012: 325). However, our findings do not corroborate previous findings. This is noteworthy as Grönlund and Milner (2006) suggested that the impact of education on the social division of welfare knowledge is higher in countries with more inegalitarian income distribution.

The second model added policy-specific motivation variables while retaining the opportunity, motivation and ability variables. Among four policy-specific motivation variables, the pensioners variable for old-age pensions was the only significant one. Living with a disabled person for social assistance, living with an unregistered employee for healthcare and living with a school-age child for education failed to show significance in terms of knowledge about the spending on corresponding policy areas. In terms of the policy-specific motivation related to old-age pensions, pensioners were 0.663 times less likely to reasonably accurately estimate pension spending ranking than the rest of the respondents.

The incorporation of the policy-specific motivation variables in the second model did not cause variables found significant in the first model to lose their significance, except for voting behaviour in education. In the second model, the odds ratio for reasonably accurate knowledge of the relative size of public spending on old-age pensions was 1.209 times greater for women than for men. Middle-income respondents were 0.770 times less likely to reasonably accurately estimate pension spending ranking than lowincome respondents. High-income respondents were 0.614 times less likely to make a reasonably accurate estimate of pension spending than low-income respondents. The regression model also demonstrated that the odds of reasonably accurate pension estimation were 2.005 times higher for respondents who live in Istanbul than for respondents who live in other cities of Turkey.

Regarding knowledge about the rank of public spending on social assistance, similar to the first model, the second model showed that the odds ratio for reasonably accurate knowledge was 0.658 times lower for respondents who live in Istanbul than for respondents who live in other cities of Turkey. Neither the variables related to the opportunitymotivation-ability framework nor the variables related to policy-specific motivation showed any significance in the second regression model for knowledge about the rank 
of healthcare spending. Only the city of residence variable showed a significant relationship with the accuracy of knowledge about the size of education spending in the second model. The regression model demonstrated that the odds of reasonably accurate education spending estimation were 1.303 times greater for respondents who live in Istanbul than for respondents who live in other cities of Turkey.

\section{Conclusion}

The analysis revealed that the Turkish public's welfare knowledge about the ranking of public spending on major social policies generally does not reflect the actual social policy context. The observation that the majority has inaccurate knowledge about the relative size of public spending on old-age pensions contradicts previous studies showing that the majority accurately estimated the relative size of widely used social benefits (e.g. TaylorGooby et al., 2003; Wilson et al., 2012). This observation is especially striking because Turkey has a pension-heavy welfare system and this is the most widely distributed social benefit in the country. The distinctiveness of the Turkish case might be explained by the cash benefits-dominated character of its welfare system. The fact that the majority is illinformed about old-age pensions raises questions about potentially distinct dynamics of knowledge acquisition concerning programmes involving cash benefits that future research can address.

Overall, this article supports the findings of Taylor-Gooby et al.'s study (2003), which reported that individuals often vary in their welfare knowledge across different social policy areas. More than half of the Turkish public have reasonably accurate knowledge about the relative sizes of public spending on universal services (healthcare and education), a finding that confirms those of earlier studies on welfare knowledge (Taylor-Gooby et al., 2003; Wilson et al., 2012; Amoah, 2020). Our findings also corroborate earlier studies that underlined a tendency for the public to overestimate public spending on social assistance for the poor (Taylor-Gooby et al., 2003; Wilson et al., 2012).

Using Turkey as a case, we applied the opportunity-motivation-ability framework of the theory of political knowledge to the case of welfare knowledge. The analysis demonstrated that opportunity variables such as gender and income performed better than motivation and ability variables in predicting welfare knowledge. Two general observations can be made in terms of the impact of opportunity variables on welfare knowledge in the Turkish case. First, different opportunity variables proved effective for each social policy area. Second, the local social policy context variable, which we measured using city of residence, emerged as the strongest predictor of the social divisions in welfare knowledge.

The observed significance of the local social policy context, which we used as another opportunity variable, in all areas of social policy (except for healthcare) confirmed our original proposition. In other words, living in the largest metropolitan city appeared to be a strong and shared determinant of having reasonably accurate knowledge about the composition of the Turkish welfare system. Nevertheless, the impact of living in Istanbul varied across policy areas. Those living in Istanbul had more accurate knowledge about the rank of old-age pension and education spending, but less accurate knowledge about the rank of social assistance spending. The positive impact of living in Istanbul on welfare knowledge might be explained by the fact that Istanbul hosts the largest share of employees working in non-agricultural sectors in the country (Akgün et al., 2017). The 
elevated level of employment in Istanbul might have created an awareness of high rates of pension contribution among its residents. The overestimation of public spending on social assistance among Istanbul residents might be due to its position as the region with the highest income inequality in Turkey (TurkStat, 2020). This finding supports our hypothesis that the prevalence of high social risks in local social policy contexts within which individuals are embedded decreases the accuracy of their welfare knowledge. Further research is needed to explore why living in Istanbul influences welfare knowledge about public spending on education.

We used voting behaviour as a variable indicating individuals' motivation to acquire knowledge. Our related hypothesis predicted that individuals voting for the governing electoral coalition in Turkey would be relatively ill-informed about the size of public spending on selected social policy areas; however, this hypothesis was rejected on two grounds. First, voting behaviour was significant only for knowledge of spending on education and in the first model, which then lost its significance once policy-specific motivation variables were incorporated in the second model. Second, when it was significant in predicting individuals' knowledge of the relative size of public spending on education, its impact was contrary to what we expected. Apart from this, we observed no statistically significant relationship between voting behaviour and welfare knowledge. In contrast to the findings of previous research (Alesina et al., 2020), our finding implies that the increased political polarisation and the government's instrumentalisation of social assistance for political purposes observed in Turkey do not manifest in public knowledge of the Turkish social policy context. Social divisions in the Turkish public's welfare knowledge do not overlap with political divisions.

This article also tested the impact of policy-specific motivation on welfare knowledge. We expected that individuals with a stake in specific social policy programmes would be better situated to have more accurate knowledge about those programmes. However, our hypothesis was partially disproved; this variable was not found significant in predicting accurate welfare knowledge about social assistance, healthcare and education. When this variable worked well in the case of old-age pensions, its impact was contrary to what we predicted. Pensioners were found to be less likely to have accurate knowledge about the relative size of public spending on old-age pensions. This interesting finding might be explained by Cramer and Toff's (2017) claim that the lived experiences of individuals mediate their exposure to and processing of political information. Pensioners might feel relatively deprived due to the perceived inadequacy of pension benefits, which could be the cause of this finding.

There are three limitations to this article. First, the dataset does not include information on media use and policy saliency, which could be used as additional opportunity and motivation predictors, respectively, of the social division of welfare knowledge. Second, the policy-specific motivation indicators used for social assistance, healthcare and education might not have performed well as they might have failed to measure individuals' eligibility for these programmes. Third, this article focuses only on welfare knowledge and its determinants, leaving aside other interesting questions such as the relationship between knowledge and welfare attitudes.

Widely shared inaccurate knowledge about the relative size of public social spending on major social policy areas in Turkey, especially in the case of old-age pensions and social assistance benefits, may undermine overall public support for redistribution, give rise to grievances in different sectors of society and potentially create an impression of a 
misguided zero-sum game involving public spending. There is ample space for political initiatives to prevent such sentiments from emerging, as Turkey is still a low spender on social benefits and public services, despite a considerable increase in the share of social expenditures in GDP over the last decade. Therefore, Turkey still has fiscal space to grow its social spending, which would improve the living conditions of both its pensioners and the poor.

Finally, largely inaccurate knowledge about the social policy context and the social division of welfare knowledge in Turkish society raise broader questions impacting the political sociology of social welfare and the politics of future social policy development. Further research can explore the issue in other countries to investigate possible links between welfare knowledge and welfare attitudes in general, and the implications of limited welfare knowledge for welfare attitudes. Including welfare knowledge in the research on welfare attitudes may contribute to broadening the dependent variables in welfare attitude analyses in both single-country cases and cross-country comparisons.

\section{References}

Akgün, I., Akgün, A. A., Demireş Özkul, B., Erkut, G., Ekizler, H., Turgut, S. H. and Zeybek, Ö. (2017) Istanbul'da Istihdam Eğilimlerinin Belirlenmesi (Determining the Employment Trends in Istanbul), Istanbul: Marmara University Press.

Alesina, A. F., Miano, A. and Stantcheva, S. (2020) The Polarization of Reality (Working Paper No: 26675), Massachusetts: National Bureau of Economic Research.

Amoah, P. A. (2020) 'Examining attitudes towards welfare in an in/security regime: evidence from Ghana', Social Policy and Society, 19, 4, 661-76.

Barnes, L., Feller, A., Haselswerdt, J. and Porter, E. (2018) 'Information, knowledge, and attitudes: an evaluation of the taxpayer receipt', The Journal of Politics, 80, 2, 701-6.

Buğra, A. (2018) 'Social policy and different dimensions of inequality in Turkey: a historical overview', Journal of Balkan and Near Eastern Studies, 20, 4, 318-31.

Buğra, A. and Keyder, Ç. (2006) 'The Turkish welfare regime in transformation', Journal of European Social Policy, 16, 3, 211-28.

Cramer, K. J. and Toff, B. (2017) 'The fact of experience: rethinking political knowledge and civic competence', Perspectives on Politics, 15, 3, 754-70.

Degen, D., Kuhn, T. and van der Brug, W. (2019) 'Granting immigrants access to social benefits? How selfinterest influences support for welfare state restrictiveness', Journal of European Social Policy, 29, 2, 148-65.

Delli Carpini, M. X. and Keeter, S. (1993) 'Measuring political knowledge: putting first things first', American Journal of Political Science, 37, 4, 1179-206.

Delli Carpini, M. X. and Keeter, S. (1996) What Americans Know about Politics and Why It Matters, New Haven: Yale University Press.

Dow, J. K. (2009) 'Gender differences in political knowledge: distinguishing characteristics-based and results-based differences', Political Behavior, 31, 1, 117-36.

Erdoğan, E. and Uyan Semerci, P. (2018) Türkiye'de Kutuplaşmanın Boyutları (The Scale of Polarization in Turkey), Istanbul: Istanbul Bilgi University Press.

Gilens, M. (2001) 'Political ignorance and collective policy preferences', American Political Science Review, 95, 2, 379-96.

Grönlund, K. and Milner, H. (2006) 'The determinants of political knowledge in comparative perspective', Scandinavian Political Studies, 29, 4, 386-406.

Jerit, J. and Barabas, J. (2012) 'Partisan perceptual bias and the information environment', The Journal of Politics, 74, 3, 672-84. 
Jerit, J., Barabas, J. and Bolsen, T. (2006) 'Citizens, knowledge, and the information environment', American Journal of Political Science, 50, 2, 266-82.

Johansson Sevä, I. (2009) 'Local contexts, social risks and social spending preferences: a multi-level approach', Acta Sociologica, 52, 3, 249-62.

Luskin, R. (1990) 'Explaining political sophistication', Political Behavior, 12, 4, 331-62.

Miller, J. and Rahn, W. (2002) Identity-based Thoughts, Feelings and Actions: How Being Influences Doing, University of Minnesota. Unpublished manuscript.

Naumann, E. (2017) 'Do increasing reform pressures change welfare state attitudes? An experimental study on population ageing, pension reform preferences, political knowledge and ideology', Ageing and Society, 37, 2, 266-94.

Organisation for Economic Co-operation and Development (OECD) (2020) Social Expenditures Database, https://www.oecd.org/social/expenditure.htm [accessed 22.08.2021].

Rudra, N. (2008) Globalization and the Race to the Bottom in Developing Countries, Cambridge: Cambridge University Press.

Stantcheva, S. (2020) Understanding Tax Policy: How do People Reason? (Working Paper No:27699), Massachusetts: National Bureau of Economic Research.

Stockemer, D. and Rocher, F. (2017) 'Age, political knowledge and electoral turnout: a case study of Canada', Commonwealth and Comparative Politics, 55, 1, 41-62.

Taylor-Gooby, P., Hastie, C. and Bromley, C. (2003) 'Querulous citizens: welfare knowledge and the limits to welfare reform', Social Policy and Administration, 37, 1, 1-20.

TurkStat (2020) Income and Living Conditions Survey - Regional Findings 2019, Ankara: TurkStat.

Wilson, S., Meagher, G. and Hermes, K. (2012) 'The social division of welfare knowledge: policy stratification and perceptions of welfare reform in Australia', Policy and Politics, 50, 3, 323-46.

World Bank (2018) Turkey's Integrated Social Assistance System, Ankara: World Bank Turkey.

Yentürk, N. (2013) 'Türkiye'de yoksullara yönelik harcamalar (Public expenditures for the poor in Turkey)', METU Studies in Development, 40, 2, 433-64.

Yentürk, N. (2015) Türkiye'de Sosyal Koruma Harcamaları: 2006-2015 (Social Protection Expenditures in Turkey: 2006-2015), Istanbul: Istanbul Bilgi University Non-Governmental Organizations Education and Research Unit.

Yörük, E. (2012) 'Welfare provision as political containment: the politics of social assistance and the Kurdish conflict in Turkey', Politics and Society, 40, 4, 517-47.

Yörük, E. (2020) 'The politics of welfare in Turkey', in G. M. Tezcür (ed.), The Oxford Handbook of Turkish Politics, Oxford: Oxford University Press, DOI: doi.org/10.1093/oxfordhb/9780190064891.013.18. 